\title{
Field tests of the susceptibility level of the housefly, Musca domestica, to five synthetic insecticides in Allahabad, India ${ }^{1)}$
}

\author{
Akifumi Hayashi, ${ }^{2)}$ Dipika Kaul, ${ }^{3)}$ Masayoshi Hatsukade, ${ }^{4)}$ Raghav Ram Tewari, ${ }^{3)}$ \\ Satoshi SHINONAGA ${ }^{2)}$ and Uma Rani AgraWAL ${ }^{3)}$ \\ ${ }^{2)}$ Department of Medical Zoology, Faculty of Medicine, Tokyo Medical \& Dental University, \\ Bunkyo-ku, Tokyo I13, Japan \\ ${ }^{3)}$ Department of Zoology, University of Allahabad, Allhabad 211002, India \\ ${ }^{4)}$ Department of Applied Entomology, Faculty of Agriculture, Shizuoka University, \\ Shizuoka-shi, Shizuoka 422, Japan
}

(Received: October 24, 1994)

\begin{abstract}
A field test to ascertain susceptibility level of the housefly, Musca domestica Linnaeus, to five kinds of insecticides viz, malathion, fenitrothion, propoxor, fenothrin and permethrin, was carried out on four wild colonies collected from Allahabad, India. Impregnated filter paper method, short time contact method and residual effect test were adopted. The results of experiments reveal that the Indian houseflies are more susceptible to malathion than Takatsuki strain, but susceptibility levels for the other four insecticides were approximately the same in the two strains. Susceptibility level of Musca domestica and $M$. sorbens Wiedemann to fenothrin and permethrin was tested. Their susceptibility level was neary the same results.
\end{abstract}

Key words: houseflies, Musca domestica, insecticide susceptibility, field test, India.

\section{INTRODUCTION}

For the chemical control of houseflies, investigations on the susceptibility to insecticides are imperative. There are many reports on insecticide susceptibility of houseflies from various parts of the world (Hayashi, 1979). However, these studies have mainly adopted topical application method or some other standard method used on colonized strains in the laboratory. The results of these methods are accurate and have been confirmed by repeated trials. Nevertheless, these methods are not suitable for field trials, especially under high temperature conditions prevailing in tropical countries. Besides, colonization of flies is difficult and after colonization of flies, it takes many days before the test can be performed. On the contrary, impregnated filter paper method is simple and the results can be obtained immediately. The authors tried this method on wild housefly colonies from Allahabad, India. At the

\footnotetext{
1) The present study was supported by the Grant-in-Aid for Monbusho International Scientific Research Program (Field Research) in 1994 (Grant No. 04041043) to Tokyo Medical \& Dental University.

2) 林 晃史・篠永 哲：東京医科歯科大学医学部医動物学教室（T 113 東京都文京区湯島 1-5-45）

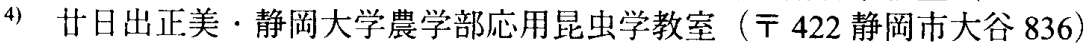


same time, short time contact method and residual effect test were carried out. In the present paper, the authors report results of field tests on susceptibility to five synthetic insecticides, namely malathion, fenitrothion, propoxor, fenothrin and permethrin.

\section{MATERIALS AND METHODS}

Flies

Houseflies, Musca domestica Linnaeus, used in this study were collected in Allahabad and two townships in Allahabad district from 1st to 20th July 1994. The places are as follows:

1). Vegetable market, Katra, Allahabad

2). Vegetable market, Mundera, Allahabad

3). Sweet meat shops, Phaphamau Township, Allahabad District

4). Sweet meat shops, Hanumanganj Township, $28 \mathrm{~km}$ E. of Allahabad, Allahabad District

Flies were collected by sweeping nets and kept in cages and taken back to the laboratory as soon as possible. They are used for tests after feeding fruit nector.

For comparing susceptibility levels, Musca sorbens Wiedemann was collected from garbage heaps thrown out of houses and shops and experimented by the same way.

\section{Insecticides}

Insecticides used in this study are:

1). Malathion, $O, O$-dimethyl $S$-(1,2-dicarboethoxy) ethyl phosphorodithioate (purity, $88.4 \%)$

2). Fenitrothion, $O, O$-dimethyl $O$-4-nitro- $m$-tolyl phosphorothioate (purity, $98.3 \%$ )

3). Propoxor, $O$-isopropoxyphenyl methylcarbamate (purity, $92.0 \%$ )

4). Permethrin, 3-phenoxybenzyl dl-cis/trans-3-(2,2-dichlorovinyl) 2-dimethyl-1-cyclopropane carboxylate (purity, 92.5\%)

5). Fenothrin, 3-phenoxybenzyl d-cis/trans-chrysanthemate (purity, $88.5 \%$ )

One $\mathrm{ml}$ of $0.5 \%$ acetone solution of each insecticide was applied on to each filter paper (Toyo-roshi, no. $1,9 \mathrm{~cm}$ in diameter) and dried at room temperature. The filter papers were then wrapped in aluminium foil and kept in refrigerator prior to test.

\section{Methods}

\section{Impregnated filter paper method}

About 10 houseflies were transferred into petri dishes $(7.5 \times 1.5 \mathrm{~cm})$ containing insecticide impregnated filter paper. For transferring flies, a test tube was used. Ether or other anesthetic chemicals were not used in the method. For each insecticide, 3 to 5 sets of replicate petri dishes were prepared. For control, flies were transferred in petri dishes without impregnated filter paper. 
Number of knocked down flies were counted at prescribed time points and $\mathrm{KT}_{50}$ was calculated. The filter papers were kept for residual effect test to be performed on days 3,5 and 30 .

\section{Short time contact method}

Flies were transferred into petri dishes containing insecticide impregnated filter paper as in the impregnated filter paper method. The flies were removed into clean glass jars after remaining in contact with the filter paper. The time of removal was 1 minute in case of permethrin and fenothrin and 5 minutes in case of propoxor and fenitrothion. Short time contact method was not tried for malathion as it was least effective in impregnated filter paper method. Number of knocked down flies were recorded at prescribed time points. Finally mortality was recorded after 24 hours.

\section{Residual effect test}

To examine residual effect of insecticides, filter papers used on day 1 were used for impregnated filter paper method on days 3,5 and 30 .

Comparative study of the susceptibility level of Musca sorbens and $\mathrm{M}$. domestica

Flies were collected from Mundera and Hanumanganj. The flies were anethetized by ether and the two species were separated and transferred into clean petri dishes. After the flies had completely recovered, susceptibility level was tested by impregnated filter paper method.

\section{RESULTS AND DISCUSSION}

\section{Impregnated filter paper method}

The results of the impregnated filter paper method are shown in Table 1. The efficiency of each insecticide to thee housefly colonies from the four locations were follwing order.

Table 1. $\mathrm{KT}_{50}$ values of 4 housefly colonies from Allahabad by impregnated filter paper method.

\begin{tabular}{lccccc}
\hline \multirow{2}{*}{ Colonies } & \multicolumn{5}{c}{ Insecticides } \\
\cline { 2 - 5 } & Malathion & Fenitrothion & Propoxor & Fenothrin & Permethrin \\
\hline \multirow{2}{*}{ Katra } & $93^{\prime} 40^{\prime \prime}$ & $60^{\prime} 30^{\prime \prime}$ & $29^{\prime} 00^{\prime \prime}$ & $10^{\prime} 03^{\prime \prime}$ & $8^{\prime} 21^{\prime \prime}$ \\
& $(53)$ & $(41)$ & $(60)$ & $(55)$ & $(65)$ \\
Mundera & $28^{\prime} 10^{\prime \prime}$ & $27^{\prime} 40^{\prime \prime}$ & $15^{\prime} 44^{\prime \prime}$ & $8^{\prime} 44^{\prime \prime}$ & $9^{\prime} 10^{\prime \prime}$ \\
& $(68)$ & $(67)$ & $(54)$ & $(25)$ & $(26)$ \\
Phaphamau & $145^{\prime} 10^{\prime \prime}$ & $66^{\prime} 20^{\prime \prime}$ & $66^{\prime} 20^{\prime \prime}$ & $7^{\prime} 13^{\prime \prime}$ & $8^{\prime} 32^{\prime \prime}$ \\
& $(68)$ & $(67)$ & $(67)$ & $(57)$ & $(62)$ \\
Hanumanganj & $52^{\prime} 40^{\prime \prime}$ & $47^{\prime} 00^{\prime \prime}$ & $24^{\prime} 00^{\prime \prime}$ & $6^{\prime} 21^{\prime \prime}$ & $8^{\prime} 45^{\prime \prime}$ \\
& $(56)$ & $(52)$ & $(60)$ & $(58)$ & $(72)$ \\
\hline
\end{tabular}

( ): No. of flies used. 
1). Katra

$$
\text { Permethrin }>\text { Fenothrin }>\text { Propoxor }>\text { Fenitrothion }>\text { Malathion }
$$

2). Mundera

$$
\text { Fenothrin }>\text { Permethrin }>\text { Propoxor }>\text { Fenitrothion }>\text { Malathion }
$$

3). Phaphamau

$$
\text { Fenothrin }>\text { Permethrin }>\text { Propoxor }>\text { Fenitrothion }>\text { Malathion }
$$

4). Hanumanganj

Fenothrin $>$ Permethrin $>$ Propoxor $>$ Fenitrothion $>$ Malathion

A comparison of the efficiency of each insecticide shows that fenothrin was most effective, followed by permethrin, propoxor, fenitrothion and malathion. These results are more or less similar to the Japanese housefly colonies (Hayashi et al., 1985).

The susceptibility level of Indian colonies for the 5 kinds of insecticides were:

Malathion: The susceptibility level to malathion was very low in flies from every place, however, $\mathrm{KT}_{50}$ value of flies from Mundera was fastest $\left(28^{\prime} 10^{\prime \prime}\right)$, followed by Hanumanganj, Katra and Phaphamau colonies. Difference between $\mathrm{KT}_{50}$ value of Mundera and Phaphamau colonies was about 5 times.

Fenitrothion: The susceptibility level to fenitrothion was higher than that to malathion in flies from each collection site. $\mathrm{KT}_{50}$ value of Mundera colony was fastest $\left(27^{\prime} 40^{\prime \prime}\right)$ followed by Hanumanganj, Katra and Phaphamau colonies. Difference between $\mathrm{KT}_{50}$ value of flies from Mundera and Phaphamau was about 2.4 times.

Propoxor: The susceptiblility level to Propoxor was more than that of malathion and fenitrothion. The flies of Mundera are most susceptible, and the difference between flies from the other places were not large. It seems that propoxor is more effective than malathion and fenitrothion for houseflies in Allahabad district.

Fenothrin: Fenothrin showed greater susceptibility than malathion, fenitrothion and propoxor. Hanumanganj flies showed highest susceptibility value and Katra flies showed lowest value. However, difference between Hanumanganj and Katra was less than 2 times.

Permethrin: Like fenothrin, permethrin is highly effective. $\mathrm{KT}_{50}$ value of flies from the four places was more or less similar.

\section{Short time contact method}

The results of the short time contact method are shown in Table 2. The efficiency of the insecticides is evaluated in terms of mortality after 24 hours. The results of the test show that Katra colony was more susceptible to all insecticides except malathion. The reason for 
Table 2. Knock down rate (\%) of housefly colonies from Katra and Phaphamau by short time contact method.

\begin{tabular}{ccccccccc}
\hline \multicolumn{7}{c}{} & \multicolumn{7}{c}{ Insecticides } \\
\hline \multirow{2}{*}{ Times } & \multicolumn{2}{c}{ Fenitrothion } & \multicolumn{2}{c}{ Propoxor } & \multicolumn{2}{c}{ Permethrin } & Fenothrin \\
\cline { 2 - 9 } & Katra & Phaphamau & Katra & Phaphamau & Katra & Phaphamau & Katra & Phaphamau \\
\hline & $(\%)$ & $(\%)$ & $(\%)$ & $(\%)$ & $(\%)$ & $(\%)$ & $(\%)$ & $(\%)$ \\
5 & 3.0 & 0.0 & 0.0 & 0.0 & 6.1 & 10.5 & 13.0 & 9.4 \\
10 & 0.0 & 0.0 & 0.0 & 3.7 & 6.1 & 15.4 & 17.4 & 15.6 \\
20 & 2.7 & 3.4 & 0.0 & 18.5 & 12.1 & 30.8 & 21.7 & 18.8 \\
30 & 14.3 & 17.4 & 0.0 & 22.2 & 15.2 & 30.8 & 26.1 & 34.4 \\
60 & 21.4 & 34.5 & 5.6 & 25.9 & 15.2 & 48.7 & 39.1 & 34.4 \\
90 & 25.0 & 34.5 & 5.6 & 22.2 & 15.2 & 41.0 & 21.7 & 34.4 \\
120 min & 32.1 & 56.7 & 5.6 & 29.6 & 12.1 & 46.2 & 26.1 & 48.3 \\
\hline 24 hrs & 53.6 & 72.4 & 27.8 & 70.4 & 48.5 & 71.8 & 69.6 & 68.7 \\
\hline \multirow{2}{*}{ No. of flies } & 28 & 29 & 18 & 27 & 33 & 39 & 23 & 32 \\
\hline
\end{tabular}

Time of contact $=5 \mathrm{~min}$ : Fenitrothion and propoxor. $1 \mathrm{~min}$ : Fenothrin and permethrin.

this is not clear.

The efficiency of 4 insecticides on Katra and Phaphamau colonies evaluated by mortality after 24 hours dropped down in the following order:

1). Katra.

$$
\begin{aligned}
& \text { Fenothrin }>\text { Fenitrothion }>\text { Permethrin }>\text { Propoxor } \\
& \begin{array}{llll}
(67.6 \%) & (53.6 \%) & (48.5 \%) & (27.8 \%)
\end{array}
\end{aligned}
$$

2). Phaphamau.

$$
\begin{array}{cccc}
\text { Fenitrothion }>\text { Permethrin }>\text { Propoxor }>\text { Fenothrin } \\
\begin{array}{cccc}
(72.4 \%) & (71.8 \%) & (70.4 \%) & (68.7 \%)
\end{array}
\end{array}
$$

It seems that the two pyrethroidal insecticides, fenothrin and permethrin, are highly effective in short time contact.

\section{Residual effect test}

For the control of adult houseflies, residual effect of the insecticides are also required. Residual effect of fenothrin, permethrin and propoxor were evaluated on flies from Katra colony. Filter papers tested on day 1 were kept for exposed at room temperature in the laboratory and again tested on day 3,5 and 30. The results are shown in Table 3. The efficiency of insecticides tested were evaluated by the value of $\mathrm{KT}_{50}$. The efficiency dropped down in the following order: 
Table 3. Residual effect of three insecticides by impregnated filter paper method. Shown at day 1, 3, 5 and 30 after insecticide treatment.

\begin{tabular}{|c|c|c|c|c|}
\hline & \multicolumn{4}{|c|}{ Day after insecticide treatment } \\
\hline & Day 1 & Day 3 & Day 5 & Day 30 \\
\hline \multirow[t]{2}{*}{ Permethrin } & $8^{\prime} 45^{\prime \prime}$ & $8^{\prime} 21^{\prime \prime}$ & $8^{\prime} 20^{\prime \prime}$ & $6^{\prime} 21^{\prime \prime}$ \\
\hline & $(83)$ & $(60)$ & $(69)$ & $(47)$ \\
\hline \multirow[t]{2}{*}{ Fenothrin } & $7^{\prime} 07^{\prime \prime}$ & $7^{\prime} 48^{\prime \prime}$ & $6^{\prime} 57^{\prime \prime}$ & $6^{\prime} 50^{\prime \prime}$ \\
\hline & $(63)$ & $(62)$ & $(76)$ & (64) \\
\hline \multirow[t]{2}{*}{ Propoxor } & $39^{\prime} 10^{\prime \prime}$ & $55^{\prime} 20^{\prime \prime}$ & $77^{\prime} 50^{\prime \prime}$ & $100^{\prime *}$ \\
\hline & $(63)$ & $(81)$ & $(68)$ & (46) \\
\hline \multicolumn{5}{|c|}{$\begin{array}{l}\text { ( ): No. of flies tested. } \\
* \quad 24 \text { hrs ( } 100 \% \text { mortality). }\end{array}$} \\
\hline \multicolumn{5}{|l|}{ Table 4.} \\
\hline \multirow{2}{*}{ Colonies } & \multicolumn{2}{|c|}{ Permethrin } & \multicolumn{2}{|c|}{ Fenothrin } \\
\hline & domestica & sorbens & domestica & sorbens \\
\hline \multirow[t]{2}{*}{ Mundera } & $9^{\prime} 10^{\prime \prime}$ & $8^{\prime} 10^{\prime \prime}$ & $8^{\prime} 44^{\prime \prime}$ & $8^{\prime} 10^{\prime \prime}$ \\
\hline & $(26)$ & $(37)$ & (19) & $(25)$ \\
\hline \multirow[t]{2}{*}{ Hanumanganj } & $8^{\prime} 45^{\prime \prime}$ & $7^{\prime} 48^{\prime \prime}$ & $6^{\prime} 21^{\prime \prime}$ & $5^{\prime} 55^{\prime \prime}$ \\
\hline & $(72)$ & $(65)$ & $(58)$ & $(60)$ \\
\hline
\end{tabular}

( ): No. of flies used.

\section{Fenothrin $>$ Permethrin $>$ Propoxor}

There were no significant differences between day 1,3 and 5 in case of filter paper treated with fenothrin and permethrin. However, the efficiency of propoxor showed a rapid decline. Thus these results suggest that fenothrin and permethrin are effective insecticides for the housefly control in Allahabad and neighbouring townships.

The susceptibility level of Musca sorbens

In the wild colony of $M$. domestica, Musca sorbens are frequently mixed in tropical countries. In Allahabad, we observed many $M$. sorbens around garbage and heaps thrown out of houses and shops. To compare the susceptibility level of $M$. domestica and $M$. sorbens, two insecticides, fenothrin and permethrin were tested by impregnated filter paper method on Mundera and Hanumanganj mixed colonies. The results were as shown in Table 4. The results of the test showed that the susceptibility level of both the species to these insecticides was nearly the same. 


\section{ACKNOWLEDGEMENTS}

Thanks are due to Professor H. R. Singh, Head of Department of Zoology, University of Allahabad, for providing necessary facilities.

\section{REFERRENCES}

Hayashi, A. (1979): Studies on the susceptibility of houseflies to various synthetic insecticides in Japan, Southeast Asia and South Pacific area. Ochanomizu Med. J., 27: 101-131.

Hayashi, A. and M. Fujimagari (1985): On the resistance to pyrethroids of houseflies in Chiba and Tohoku areas. Bull. Public Health Lab. Chiba Pref., 10: 12-15.

\section{摘 要 \\ インド，アラハバードにおけるイエバエの野外殺虫試験}

今日まで，世界各地からイエバエを採集して，各種の殺虫剤に対する感受性について 調査を行なってきた。しかし，いずれの場合も実験室に持ち帰り，一度，飼育して増殖し た個体群を用いたものであった，今回は，薬剤感受性の程度を現地で．迅速且つ簡便に実 験出来る方法を知る事を目的とし実験を行なった，実験方法は，準備が容易な濾紙接触法 により，速効性や残効性を調べた，実験に用いたイエバエは，インドのアラハバード市内 と周辺の地域の 4 か所で採集した個体群である。実験に使用した殺虫剂は, malathion, fenitrothion, permethrin, fenothrin および propoxorの 5 種類である。実験の結果，継続接触法では， permethrin と fenothrin が優れた速効性を示し, propoxor $>$ fenitrothion $>$ malathionの順に感受 性が低下した。 また，採集地別の感受性は，速効性のある殺虫剤において，その差が大き い傾向が強かった。短時間接触法の結果について見ると，fenothrinの効果が高かった。 Katra（市内）で採集したイエバエは，fenitrothion, permethrin および propoxor に対する感受 性が郊外の Phaphamau で採集したものよりも低く，感受性に差異が認められた。残效性に ついては, permethrin と fenothrin ともに優れていた. Permethrinについては，処理值後の $\mathrm{KT}_{50}$ 值が 8 分 45 秒に対し 30 日後の処理面で 6 分 21 秒と低下は認められなかった。しかし, propoxor は, permethrin や fenothrin に比較して遅効性で, 残効性も低下しやすい傾向が認め られた。以上の結果から，この実験の範囲では，濾紙接触法は，現地で迅速に状況を知る 方法として，実用性が高いといえる，なお，malathionに対する感受性は，日本産イエバエ では見られない，高い感受性であった。また，pyrethroid 剤が，propoxorよりも高い残効性 をしめした事は興味ぶかい点である。このほか，今回の実験で，イエバエとフタスジイエ バエの感受性に差異が無い事がわかった. 